\section{Erkroppsmasseindeks et utdatert helsemål?}

Fettprosent kan være et bedre mål for god helse enn kroppsmasseindeks, viser ny studie.

Enkelte pasientgrupper har lavere total dødelighet ved moderat økt kroppsmasseindeks (body mass index, BMI). Dette omtales gjerne som fedme-overlevelsesparadokset. En kanadisk kohortstudie har undersøkt om fettprosent er en bedre prognostisk faktor for totaldødelighet enn kroppsmasseindeks (1).

Studien omfattet alle personer over 40 år som var blitt henvist til bentetthetsmålinger i byen Manitoba i Canada, dvs. rundt 50000 personer, de fleste kvinner. Kroppsfett og kroppsmasseindeks ble målt én gang ved inklusjon. Både kvinner og menn med lavest kroppsmasseindeks hadde økt mortalitet med en hasardratio på henholdsvis $1,44(95 \% \mathrm{KI} 1,30-1,59)$ og $1,45(95 \% \mathrm{KI}$ $1,17-1,79)$. I tillegg var høy kroppsfettprosent assosiert med høyere dødelighet hos begge kjønn.

Resultatene fra denne studien støtter tidligere forskning som har vist at kroppsmasseindeks ikke nødvendigvis er et godt mål på mengde kroppsfett og at lav kroppsmasseindeks kan være assosiert med sykdom og økt dødelighet, sier Jøran Hjelmesæth, som er leder for Senter for sykelig overvekt i Helse Sør-Øst og professor ved Universitetet i Oslo. Personer med subnormal kroppsmasseindeks kan ha både lite muskler og mye visceralt fett - begge deler gir hver for seg økt risiko for kardiovaskulær sykdom og død, sier han.

Studiens største svakheter er at alle deltagerne ble henvist til benmineraltetthetsmåling på klinisk indikasjon, manglende data for røykevaner og fysisk aktivitet og den høye gjennomsnittsalderen. Dette svekker studiens generaliserbarhet, sier Hjelmesæth.

\section{Kaveh Rashidi}

Tidsskriftet

\section{Litteratur}

1. Padwal R, Leslie WD, Lix LM et al. Relationship among body fat percentage, body mass index, and all-cause mortality: a cohort tudy. Ann Intern Med 2016; e-publisert 8.3.2016.

\title{
Utbredt antibiotikaresistens ved urinveisinfeksjoner
}

\author{
Resistens mot de mest brukte legemidlene mot urinveisinfeksjoner hos \\ barn er svært utbredt. Dette viser en ny metaanalyse.
}

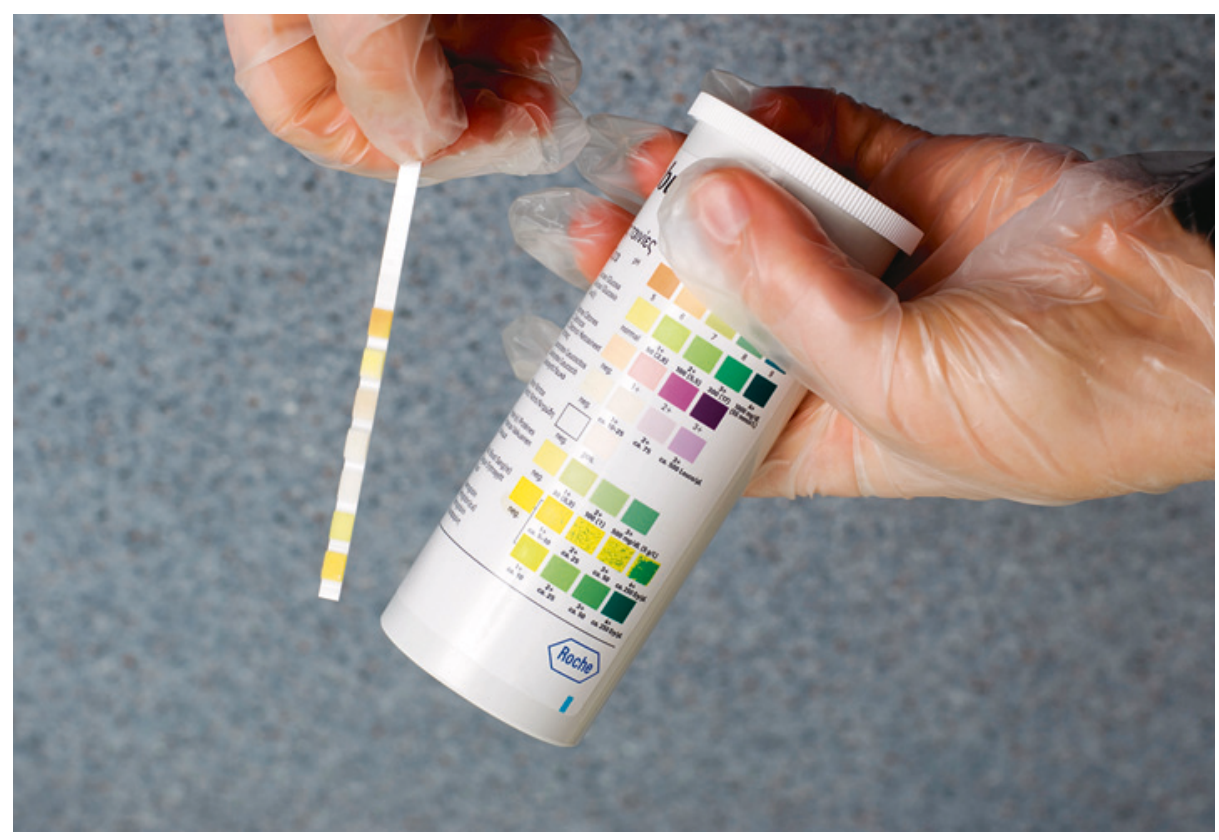

Illustrasjonsfoto: Science Photo Library

I en systematisk gjennomgang og metaanalyse av 58 studier fra 26 land er forekomsten av antibiotikaresistens hos barn og ungdom med urinveisinfeksjon som skyldtes Escherichia coli undersøkt (1). Nær 78000 dyrkningsprøver av urin danner grunnlaget for beregning av global resistens mot de mest brukte legemidlene ved urinveisinfeksjon.

I alle landene var ampicillin det antibiotikumet med høyest forekomst av resistens. I Ghana og Nigeria ble det påvist resistens mot ampicillin i alle tilfellene med urinveisinfeksjon. Sveits hadde lavest resistensforekomst mot ampicillin (41\%). I høyinntektsland var det resistens mot trimetoprim-sulfa i rundt en tredel av tilfellene, mens det i lavinntektsland var mer enn dobbelt så høy forekomst av resistens mot dette legemidlet. I lavinntektsland ble det funnet resistens mot ciprofloksacin i over en firedel av tilfellene, mot under $2 \%$ i høyinntektsland. Lavest resistens var det mot nitrofurantoin, uavhengig av hvilket land dyrkningsprøvene var fra. For samtlige antibiotiske midler ble det funnet høyere forekomst av resistens i lavinntektsland enn i høyinntektsland. Forekomsten av antibiotika- resistens i hvert enkelt land var høyere for antibiotika klassifisert som førstevalg enn for dem som ikke var det.

I en metaanalyse av fem av de inkluderte studiene ble det funnet en oddsratio på 13,23 (95\% KI 7,84-22,31) for å finne resistens hos E. coli i dyrkningsprøver fra barn som hadde fått antibiotika mot urinveisinfeksjon 1-6 måneder før prøvetaking, sammenlignet med barn som ikke hadde fått antibiotika mot urinveisinfeksjon tidligere.

Forfatterne mener at høy forekomst av resistens i lavinntektsland kan skyldes at salg av antibiotika uten resept er vanligere og at dyrkningsprøver ikke alltid tas før første behandlingsfors $ø \mathrm{k}$ har feilet.

\section{Matilde Risopatron Berg}

Holter legekontor, Nannestad

\section{Litteratur}

1. Bryce A, Hay AD, Lane IF et al. Global prevalence of antibiotic resistance in paediatric urinary tract infections caused by Escherichia coli and association with routine use of antibiotics in primary care systematic review and meta-analysis. BMJ 2016; 352: 1939. 